\title{
ACCELERATION OF SCRAPIE IN MICE BY TARGET- ORGAN TREATMENT WITH INTERFERON INDUCERS
}

\author{
Lois B. Allen* and K. W. Cochran \\ Department of Epidemiology and Virus Laboratory \\ School of Public Health and \\ Department of Pharmacology, Medical School \\ University of Michigan \\ Ann Arbor, Michigan 48104
}

\section{INTRODUCTION}

Scrapie, a disease of sheep, was well known in the eighteenth century, ${ }^{1}$ but despite a long period of study, the etiologic agent has not been clearly identified, although it is generally considered to be a virus disease. ${ }^{2}$ Observations of scrapie in sheep and laboratory animals indicate that it is an irreversibly fatal disease. ${ }^{1}$

Katz and Koprowski ${ }^{3}$ and Worthington ${ }^{4}$ indicated that scrapie neither stimulated nor altered the response of mice to interferon inducers. Also, neither exogenous interferon $^{5,8}$ nor the interferon inducers statolon, ${ }^{5}$ polyinosinic-polycytidylic acid [poly(I:C)], ${ }^{4}$ and Newcastle disease virus ${ }^{4}$ were able to alter the course of the disease in mice when administered peripherally.

Interferon inducers generally have a striking effect on viral diseases of the central nervous system other than scrapie. M5-8450, a statolon predecessor, given peripherally, was effective against poliovirus infection initiated peripherally, but not intracerebrally. ${ }^{7}$ However, M5-8450 was quite effective against intracerebrally inoculated virus when administered by the same route. ${ }^{8}$ Similarly, pretreatment with interferon inducers intracerebrally was more effective than intraperitoneal treatment in preventing vaccinial encephalitis in mice. ${ }^{9}$ The latter study suggested that once a virus reached the brain, peripheral treatment with exogenous interferon or inducers had little effect on progression of the disease.

Since the technique of direct intracerebral treatment had been effective against other virus diseases of the central nervous system, the present study was undertaken to determine its effectiveness in scrapie.

\section{METHODS}

Animals. Laboratory-bred female Swiss-Webster mice weighing 15-20 g were used in these studies.

Interferon Inducers. Poly $(\mathrm{I}: \mathrm{C})$ was purchased from Microbiological Associates, Bethesda, Md., as a solution containing $1 \mathrm{mg} / \mathrm{ml}$. Statolon was supplied by Dr. W. J. Kleinschmidt, Lilly Research Laboratories, Indianapolis, Ind. Sendai virus, provided by Professor Minuse of this laboratory, was used as allantoic fluid containing 512 hemagglutination (HA) units $/ \mathrm{ml}$.

*Supported by U. S. Public Health Service Training Grant 5 T1 AI 00060 from the National Institute of Allergy and Infectious Diseases. Present address: ICN Pharmaceuticals, Inc., Nucleic Acid Research Institute, Irvine, Calif. 92715. Part of this material is from a dissertation submitted in partial fulfillment of requirements for the degree of Doctor of Philosophy, Rackham School of Graduate Studies, University of Michigan. 
TABLE 1

Survival Times of Mice Treated Intracerebrally with INTerferon Inducers 24 hr PRIOR TO INTRACEREBRAL SCRAPIE AGENT INOCULATION

\begin{tabular}{|c|c|c|c|c|c|}
\hline Inducer & Dose & $\begin{array}{c}\text { Mean } \\
\text { Survival } \\
\text { Time } \\
\text { (days) }\end{array}$ & $\begin{array}{l}\text { Range } \\
\text { (days) }\end{array}$ & $\begin{array}{c}\text { Survival } \\
\text { Time } \\
\text { Difference } \\
\text { (days) }\end{array}$ & $\begin{array}{c}\text { Survival } \\
\text { Time } \\
\text { Difference } \\
\mathrm{p}^{*}\end{array}$ \\
\hline Saline & $0.03 \mathrm{ml}$ & 158.2 & $132-169$ & & \\
\hline Statolon & $45 \mu \mathrm{g}$ & 149.5 & $129-170$ & 8.7 & $>0.05$ \\
\hline Saline & $0.03 \mathrm{ml}$ & 162.1 & $148 \cdot 183$ & & \\
\hline \multirow[t]{2}{*}{ Poly $(I: C)$} & $0.3 \mu \mathrm{g}$ & 155 & $134-170$ & 7.1 & $>0.05$ \\
\hline & $30.0 \mu \mathrm{g}$ & 154.8 & $142-175$ & 7.3 & $>0.05$ \\
\hline Saline & $0.03 \mathrm{ml}$ & 162.1 & $148-183$ & & \\
\hline $\begin{array}{r}\text { Sendai } \\
\text { virus }\end{array}$ & $\begin{array}{r}1.5 \mathrm{HA} \\
\text { units }\end{array}$ & 144.8 & $129-156$ & 17.3 & $<0.01$ \\
\hline
\end{tabular}

*Probability determined by t-test.

Scrapie Agent. The Chandler strain of mouse-adapted scrapie agent, provided by Dr. W. J. Hadlow, was used as a $1 \%$ saline suspension of the sixth mouse brain passage.

Experimental Method. Groups of 20 mice were infected by intracerebral inoculation of $10^{4.8} \mathrm{LD}_{50}$ of scrapie agent. The disease was evaluated by determining the mean survival times and by following the alteration of the hindleg responses of mice as described previously. ${ }^{10}$ Animals were observed daily for deaths and weekly for hindleg responses. To compare the disease development in different groups, differences in mean survival times and mean disease scores were evaluated using the t-test. Only animals dying after termination of treatment were used to calculate the mean survival times. Interferon inducers were administered intracerebrally in volumes of $0.03 \mathrm{ml}$ starting $24 \mathrm{hr}$ before infection. Poly(I:C) was injected weekly for 8 weeks following infection. Statolon and Sendai were given biweekly for 6 and 5 weeks, respectively.

TABLE 2

Survival Times of Mice Receiving Multiple Intracerebral Treatments with Interferon Inducers Starting 24 hr prior to InTracerebral SCrapie Agent INOCULATION

\begin{tabular}{|c|c|c|c|c|c|c|}
\hline Inducer & Dose & Interval & $\begin{array}{l}\text { Mean } \\
\text { Survival } \\
\text { Time } \\
\text { (days) }\end{array}$ & $\begin{array}{l}\text { Range } \\
\text { (days) }\end{array}$ & $\begin{array}{c}\text { Survival } \\
\text { Time } \\
\text { Difference } \\
\text { (days) }\end{array}$ & $\begin{array}{c}\text { Survival } \\
\text { Time } \\
\text { Difference } \\
\mathrm{p}^{*}\end{array}$ \\
\hline Saline & $0.03 \mathrm{ml} \times 7$ & biweekly & 146.8 & $121-176$ & & \\
\hline Statolon & $45 \mu \mathrm{g} \times 7$ & biweekly & 128.3 & $97-161$ & 18.5 & $<0.001$ \\
\hline Saline & $0.03 \mathrm{ml} \times 9$ & weekly & 150.3 & $139-160$ & & \\
\hline \multirow[t]{2}{*}{ Poly(I:C) } & $0.3 \mu \mathrm{g} \times 9$ & weekly & 153.0 & $140-163$ & 2.7 & $>0.05$ \\
\hline & $30.0 \mu \mathrm{g} \times 9$ & weekly & 136.8 & $83-166$ & 13.5 & $>0.05$ \\
\hline Saline & $0.03 \mathrm{ml} \times 6$ & biweekly & 153.6 & $128-165$ & & \\
\hline $\begin{array}{r}\text { Sendai } \\
\text { virus }\end{array}$ & $\begin{array}{l}1.5 \mathrm{HA} \\
\text { units } \times 6\end{array}$ & biweekly & 131.9 & $117-148$ & 21.7 & $<0.001$ \\
\hline
\end{tabular}

*Probability determined by t-test. 


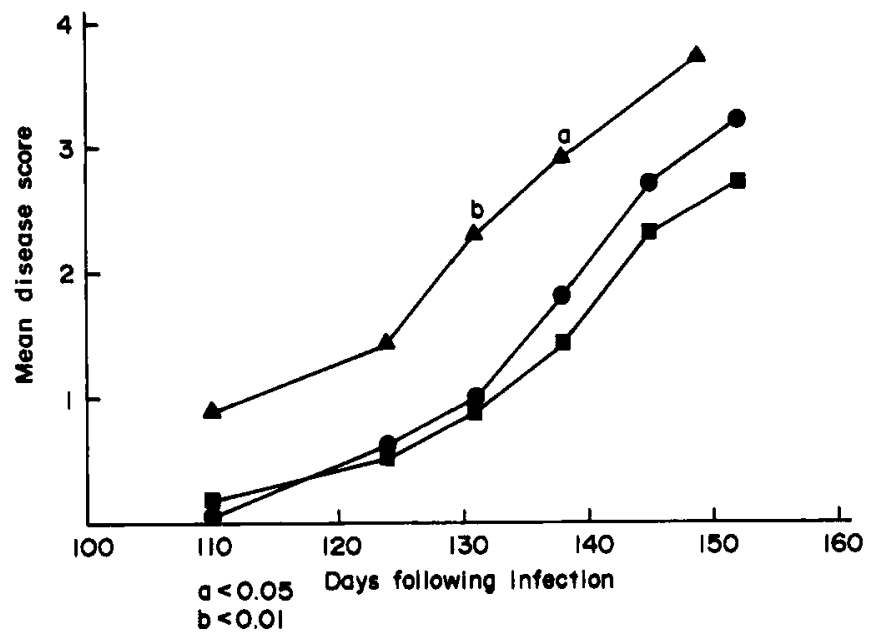

FIGURE 1. Acceleration of scrapie by poly(I:C); doses specified given intracerebrally once weekly for nine weeks, starting day before infection. $\bullet$, Saline control; $₫, 30 \mu \mathrm{g}$ poly $(\mathrm{I}: \mathrm{C}) ; \mathbf{\varpi}, 0.3$ $\mu \mathrm{g}$ poly $(\mathrm{I}: \mathrm{C})$.

\section{RESULTS}

A single intracerebral pretreatment with interferon inducers shortened the life span of scrapie-infected mice by 7.1 to 17.3 days (TABLE 1), although the only inducer that produced a significant lowering of survival time was Sendai virus. When multiple intracerebral treatments were given, only one material, the low poly $(\mathrm{I}: \mathrm{C})$ dose, failed

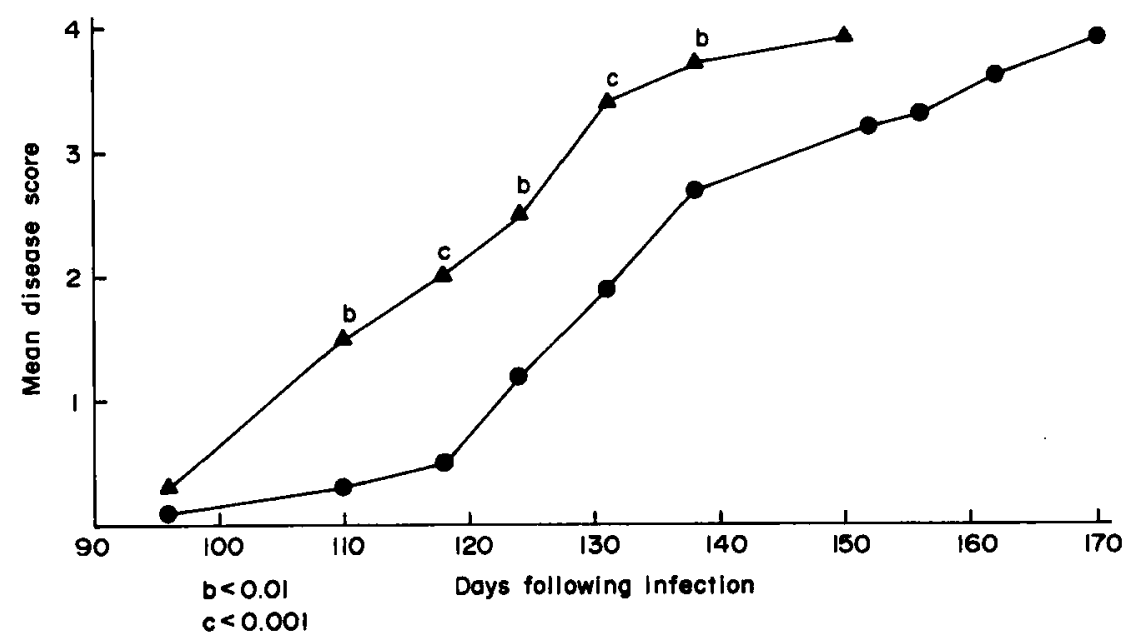

Figure 2. Acceleration of scrapie by statolon, given intracerebrally biweekly seven times, starting the day before infection. $\bullet$, Saline control; $\triangleleft, 45 \mu \mathrm{g}$ statolon. 
to shorten the life span of treated mice (TABLE 2). Statolon, Sendai, and the high dose of poly $(\mathrm{I}: \mathrm{C})$ shortened mean survival times by 13.5 to 21.7 days. The decrease seen with statolon and Sendai was significant. Four animals in the high-dose poly(I:C) group, showing signs of advanced disease, died during the treatment period; therefore, the mean survival time shown in TABLE 2 does not show the full extent off acceleration seen in this group. Although the high dose of poly(I:C) shortened the mean survival time by 13.5 days, variation within the group prevented this from being a significant difference. Multiple treatments (TABLE 2) that hastened death also accelerated the progression to all stages of the disease (FIGURES 1-3).

Uninfected animals treated with saline or interferon inducers remained normal for a period of 11 months.

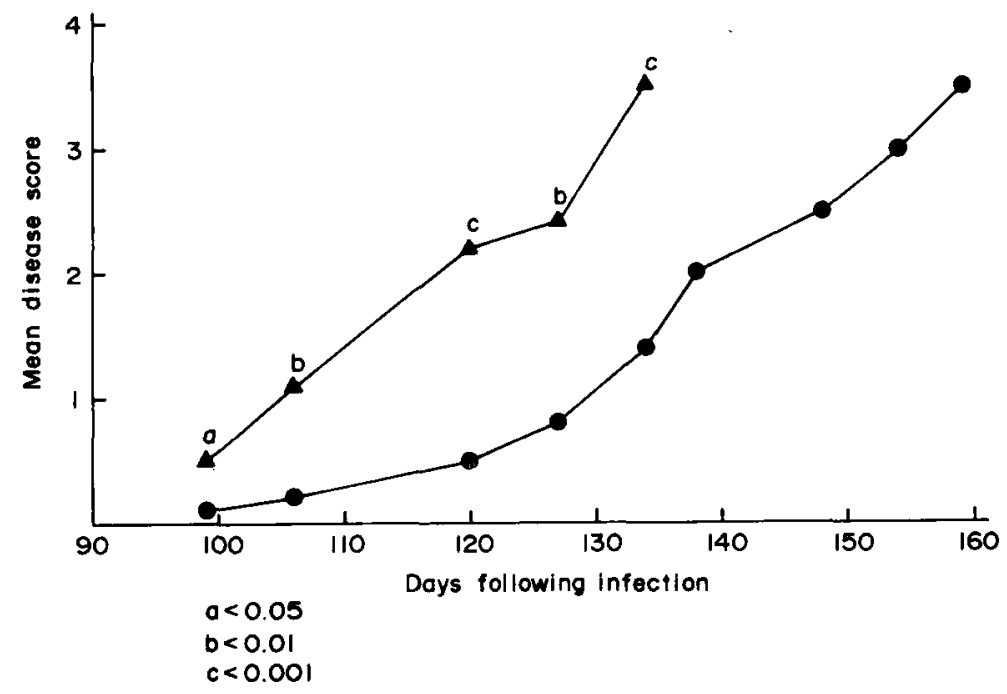

FIGURE 3. Acceleration of scrapie by Sendai virus, given intracerebrally biweekly six times starting the day before infection. $\bullet$, Saline control; $\triangleleft, 1.5 \mathrm{HA}$ units Sendai virus.

\section{DisCuSsION}

Single intracerebral treatments with interferon inducers prior to scrapie infection hastened the death of treated mice. Of the inducers tested, however, only Sendai virus significantly reduced the mean survival time of treated mice.

Multiple treatments with $0.3 \mu \mathrm{g}$ poly $(\mathrm{I}: \mathrm{C})$ produced a nonsignificant 2.7 day increase in survival time. Multiple doses of $30 \mu \mathrm{g}$ poly $(\mathrm{I}: \mathrm{C})$ and the other inducers produced greater acceleration of death than the single treatments.

Of the inducers tested, Sendai virus produced the greatest acceleration of death in treated mice. Although not lethal when injected in tracerebrally, it does replicate in mice and can cause death following intranasal instillation. Cell membranes are the major sites of replication of Sendai and the scrapie agent. Therefore, Sendai may enhance the effect of scrapie by alterating cell membranes.

None of the inducers produced apparent adverse effects in toxicity control mice. 
Nevertheless, it is possible that the repeated instillation of a foreign substance into the brain after scrapie infection might accelerate disease by an irritating effect.

Interferon inducers have been shown to stimulate resistance mechanisms other than interferon induction. Among these is a stimulation of the reticuloendothelial system by poly(I:C) and endotoxin. ${ }^{11,12}$ Also, virus-induced interferon was found to stimulate phagocytosis by mouse mononuclear cells. ${ }^{13}$ Acceleration of scrapie by interferon inducers may result from stimulation of lymphoid cells, which are believed to be important in the pathogenesis of scrapie. ${ }^{14,15}$

This study demonstrates that the course of scrapie can be altered. Even though the effect was disease enhancement, the ability to manipulate the disease may contribute to understanding the nature of the agent and the pathogenesis of the disease. Although the acceleration of disease by the interferon inducers tested may have been quite specific for scrapie, this work suggests an area for vigilance in the clinical development of interferon inducers, the possibility of enhancing or inciting a human slow disease.

\section{SUMMARY}

Interferon inducers were used in the target-organ treatment of scrapie in mice. Intracerebral treatments began $24 \mathrm{hr}$ prior to intracerebral inoculation of $10^{4.8} \mathrm{LD}_{50}$ of the Chandler strain of scrapie agent. The treatments included 30 and $0.3 \mu \mathrm{g}$ poly(I:C) given weekly 9 times, $45 \mu \mathrm{g}$ statolon given biweekly 7 times, or $1.5 \mathrm{HA}$ units of Sendai virus given biweekly 6 times. All treatments except the lower dose of poly $(\mathrm{I}: \mathrm{C})$ accelerated death in scrapie-affected mice. Compared to saline-treated control groups, $30 \mu \mathrm{g}$ poly $(\mathrm{I}: \mathrm{C})$, given weekly, shortened the mean survival time 13.5 days. Groups treated with statolon or Sendai virus had their mean survival times shortened 18.5 and 21.7 days, respectively. Infected mice were also evaluated for signs of disease at approximately weekly intervals using a numerical scoring method. Acceleration was also apparent using this parameter of disease. When treatment occurred only once, Sendai virus was the only inducer to significantly shorten the survival of mice.

\section{REFERENCES}

1. Lampert, P. W., D. C. Gajdusek \& C. J. GibBs. 1972. Subacute spongiform virus encephalopathies. Amer. J. Pathol. 68:626-646.

2. GiBBS, C. J., JR. \& D. C. GAJDUSEK. 1971. Transmission and characterization of spongiform virus encephalopathies; kuru, Creutzfeldt-Jakob disease, scrapie and mink encephalophy. Immunological diseases of the nervous system. Res. Publ. Assoc. Res. Nerv. Ment. Dis. 49:383-410.

3. KaTZ, M. \& H. KoprowsKI. 1968. Failure to demonstrate a relationship between scrapie and production of interferon in mice. Nature 219:639-640.

4. WORTHINGTON, M. 1972. Interferon system in mice infected with the scrapie agent. Infect. Immun. 6:643-645.

5. Field, E. J., G. Joyce \& A. Keith. 1969. Failure of interferon to modify scrapie in the mouse. J. Gen. Virol. 5:149-150.

6. Gresser, I. \& I. H. Pattison. 1968. An attempt to modify scrapie in mice by the administration of interferon. J. Gen. Virol. 3:295-296.

7. Powell, H. M. \& C. G. Culbertson, JR. 1953. Action of an antiviral mold filtrate against MEF 1 poliomyelitis virus in mice. Proc. Soc. Exp. Biol. Med. 83:161-163.

8. Cochran, K. W. 1954. Antiviral action of M5-8450 against poliomyelitis in mice. Fed. Proc. 13:343. 
9. Allen, L. B. \& K. W. Cochran. 1972. Target organ treatment with interferon inducers of neurot ropic virus disease. Infect. Immun. 6:819-823.

10. Cochran, K. W. \& L. B. Allen. 1970. Simple method of evaluation of scrapie in mice. Appl. Microbiol. 20:72-74.

11. Regelson, W. \& A. E. Munson. 1970. The reticuloendothelial effect of interferon inducers; polyanionic and nonpolyanionic phylaxis against microorganisms. Ann. N.Y. Acad. Sci. 173:831-841.

12. Chester, T. J., E. DeClerce \& T. C. Merigan. 1971. Effect of separate combined injections of poly rl: poly $\mathrm{rC}$ and endotoxin on reticuloendothelial activity, interferon, and antibody production in the mouse. Infect. Immun. 3:516-520.

13. Huane, K., R. M. Donahoe, F. B. Gordon \& H. R. Dresser. 1971. Enhancement of phagocytosis by interferon containing preparations. Infect. \& Immun. 4:581-588.

14. Eklund, C. M., P. C. K EnNedy \& W. J. Hadlow. 1967. Pathogenesis of scrapie virus infection in the mouse. J. Infect. Dis. 117:15-22.

15. Mould, D. L., A. Mcl. Dawson, \& J. C. RenNiE. 1970. Very early replication of scrapie in lymphocytes tissue. Nature 228:779-780. 